\title{
Some Foreshocks and Aftershocks Associated with the Moiyabana Earthquake of 2017 in Botswana
}

\author{
Thebeetsile A. Olebetse1, Matlhogonolo L. Mmese1, \\ Rapelang E. Simon ${ }^{*}$, Joseph Maritinkole² \\ ${ }^{1}$ University of Botswana, Gaborone, Botswana \\ ${ }^{2}$ Botswana Geoscience Institute, Lobatse, Botswana \\ Email: ^simonre@ub.ac.bw
}

How to cite this paper: Olebetse, T.A., Mmese, M.L., Simon, R.E. and Maritinkole, J. (2020) Some Foreshocks and Aftershocks Associated with the Moiyabana Earthquake of 2017 in Botswana. International Journal of Geosciences, 11, 238-250.

https://doi.org/10.4236/ijg.2020.114013

Received: January 14, 2020

Accepted: April 24, 2020

Published: April 27, 2020

Copyright $\odot 2020$ by author(s) and Scientific Research Publishing Inc. This work is licensed under the Creative Commons Attribution International License (CC BY 4.0).

http://creativecommons.org/licenses/by/4.0/

\begin{abstract}
On the $3^{\text {rd }}$ of April 2017, an earthquake of moment magnitude 6.5 occurred near Moiyabana in central Botswana. This paper is aimed at studying the spatial distribution of the foreshock and aftershock sequences associated with the Moiyabana earthquake. The foreshocks and aftershocks data used were from the Botswana Geoscience Institute (BGI) and the Seisan software was used to analyze the foreshock and aftershock events. The analyses revealed nine epicenter locations of foreshocks which are spread out across the country and most of them are located in the central and southern parts of Botswana, while the aftershocks are clustered around the mainshock. Although five of the nine foreshocks occurred far from the boundaries of major tectonic units, the other four occurred near key features such as the Zoetfontein, Lecha and Chobe faults. The spatial distribution of aftershocks indicates that the stress released by the mainshock, re-activated the planes of weakness in the vicinity of the mainshock and farther away from the mainshock. Hence, this affected the Zoetfontein fault, the boundary between Passarge basin and Magondi belt and the boundary between the Kaapvaal craton and Limpopo mobile belt. The aftershocks also show a northwest-southeast trend, which probably indicates the rupture plane; and mainly lie within the Limpopo mobile belt that is sandwiched between the Kaapvaal craton to the south and Zimbabwe craton to the north. Furthermore, the aftershocks concentration to the south reveals a close relation in demarcating the boundary of the Kaapvaal craton and the Limpopo mobile belt.
\end{abstract}

\section{Keywords}

Botswana, Foreshocks, Aftershocks, Earthquake, Moiyabana, Kaapvaal Craton, 


\section{Introduction}

An earthquake or tremor is the sudden movement of the ground caused by the rapid release of energy that has accumulated along fault zones in the earth's crust [1]. Seismographs are the primary instruments used by seismologists to study earthquakes. Although earthquakes can be very destructive, they play a vital role in studying the interior of the earth. Seismologists have adopted two widely used scales, which are the Richter scale and Mercalli scale, to measure the energy released by an earthquake [1]. The Richter magnitude is widely used because it can be computed within a few hours of an occurrence of an earthquake but it underestimates the size of the largest earthquakes hence the moment magnitude, $\mathrm{M}_{\mathrm{w}}$, based on the seismic moment has been introduced [2].

According to [3], the largest earthquakes occur in a seismic cycle in which the interseismic stage makes up most of the cycle and steady motion occurs away from the fault, but the fault is "locked". Prior to rupture, there is the preseismic stage that can be associated with foreshocks (small earthquakes). The mainshock (large earthquake) marks the coseismic phase during which rapid motion on the fault generates seismic waves [3]. Aftershocks form the postseismic phase which is the last part of the cycle that occurs after the mainshock. Foreshocks can indicate the buildup of strain in an area and a number of them might warn of an impending earthquake [2]. Any aftershocks will be along the fault plane and are believed to reveal the rupture plane because most of them lie on a plane that also includes the mainshock [2]. Earthquakes are thought to trigger aftershocks either from the dynamic effects of their radiated seismic waves or the resulting permanent static stress changes [4].

The main aim of this study is to use data recorded by the Network of Autonomously Recording Seismographs (NARS) project to understand the spatial distribution of epicentres of foreshocks and aftershocks associated with the Moiyabana earthquake that occurred in central Botswana on the $3^{\text {rd }}$ April 2017. The mainshock had a moment magnitude, $\mathrm{M}_{\mathrm{w}}$ of 6.5 as shown in Figure 1 and occurred at a depth of about $29 \mathrm{~km}$ [5]. The Moiyabana earthquake had an oblique normal faulting mechanism [5]. This is the third largest earthquake with magnitude greater than 6 to be instrumentally recorded in Botswana and the first largest in central Botswana where the continent is generally stable. The occurrence of large earthquakes in stable continental regions is a rare phenomenon and it is relatively not understood [5]. Plotting the hypocentral location of aftershocks is particularly useful since the spatial distribution of aftershocks within the first days will show the extension of the ruptured surface [6].

The paper is organized in the following way. We start with a brief summary of the geology and seismicity of Botswana; which is followed by a brief description 


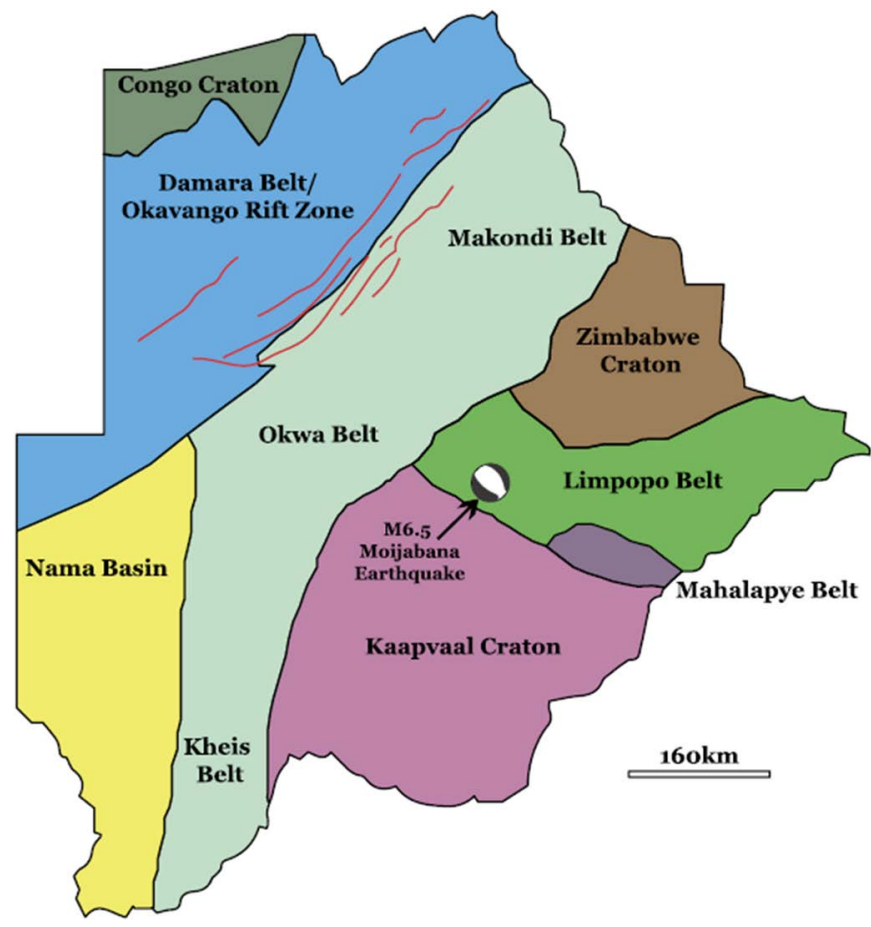

Figure 1. Schematic geologic map of Archean terranes in Botswana based on compilation of maps and information [5].

of the methodology used. The seismic event parameters of both foreshocks and aftershocks and their spatial distributions are then presented; and finally the discussions and the conclusions are given.

\section{Brief Geology of Botswana}

The geology of Botswana is generally obscured by Cretaceous (145 - 66 million years ago $(\mathrm{Ma})$ ) to recent Kalahari beds, consisting mainly of Aeolian sands. Archean (4000 - $2500 \mathrm{Ma}$ ) and Paleoproterozoic (2500 - $1600 \mathrm{Ma})$ rocks occupy the eastern part of the country [7]. A sequence of Mesoproterozoic (1600 - 1000 $\mathrm{Ma})$ and Neoproterozoic (1000 - $541 \mathrm{Ma})$, northeast-striking rocks that are continuation of Proterozoic rocks of Namibia, cross into western Botswana [7]. Karoo sediments, mainly of continental-fluvial origin and thick basaltic lavas overlie Precambrian rocks in the east of the country. The Archean Kaapvaal and Zimbabwe cratons (Kalahari craton) form the nucleus of the crust beneath Botswana. The oldest high grade metamorphic rocks are found in the Kaapvaal craton. It is characterized by the occurrence of gneissic granitoids and associated greenstone belts [8] [9].

Geophysical surveys have shown that the ironstone formations and associated amphiboles of the Kraaipan Group extend for $\sim 50 \mathrm{~km}$ northwards. The gneisses and granitoids are separated by a west northwest orientated shear zone. The granites associated with the Kaapvaal craton are the youngest rocks and they were emplaced at about $2780 \mathrm{Ma}$, these include the Gaborone granite and the Lobatse group volcanics just to name a few [9]. The Zimbabwe craton is a granite and 
greenstone terrane. There is a series of porphyritic granites and migmatites that underlie the Tati-Vumba greenstone belts that are in turn overlain by layered gneisses, with the Tati greenstone belt having a greater volume of early gneissic granites than any other greenstone belt. A major north-northeast oriented fault is with the formation of new greenstone belts west of Maitengwe [9].

On the western zone of the Limpopo belt, occurs the Shashoko Hiatus, this is a major structure that separates the Zimbabwe craton from the Shashe mobile belt [9]. This is an extensive migmatite terrane that underlies the Vumba greenstone belt, the occurrence of gneisses and porphyritic granite. The Kaapvaal and Zimbabwe cratons are sutured together by the Archean and Paleoproterozoic Limpopo belt. This belt was the result of the collision of these two cratons and it is associated with highly metamorphosed granite-greenstone and granulite terranes [10]. Limpopo belt is subdivided into four tectonic zones which are the western, northern, central and southern marginal zones. The Northern Marginal Zone does not extend into Botswana while the western marginal zone is mostly exposed in Francistown. It comprises of a tectonic mixture of lithologies dominated by strongly deformed meta-magmatic rocks.

The central zone is associated with major fold structures that trend northsouth while the southern zone has an east-west structural trend [9]. According to [9], the latter zones are associated with banded gneisses, meta-sedimentary rocks and amphibolites although the central zone has more diverse lithologies. The largest belt is the Kheis-Okwa-Magondi belt and it is bound by the Kalahari suture zone (KSZ). It runs from southwest to northeast Botswana [8]. The Kheis is associated with siliclastic rocks [11] whereas the Okwa is a magnetic feature lying northeast of the Kheis province and central part of Botswana. Exposures of this belt are in the Okwa valley and it comprises of deformed mafic and felsic magmatic rocks which are in fault contact with a number of supracrustal units. These are dated at about $2050 \mathrm{Ma}$ [9].

The Magondi belt is a magnetic belt which is located on the northeastern part of Botswana and it is buried by the Karoo and Kalahari sediments. It is exposed in the Sua pan area and it is mostly comprised of an un-deformed granite (younger) and older migmatites which is dated at 2.0 giga years ago ( $\mathrm{Ga}$ ) [9]. Figure 2 shows the Kalahari craton, Limpopo mobile belt and other tectonic units of Botswana, the mainshock occurred along the junction of the Limpopo mobile belt and the Kaapvaal craton (Figure 1) in the Central Kalahari Game Reserve (CKGR) near the Moiyabana village.

Moiyabana is located in the central part of Botswana within the Limpopo belt. The Limpopo belt is sandwiched between two Archean cratons, which are the Kaapvaal and Zimbabwe cratons. The Limpopo belt was formed by a series of tectonic, magmatic and metamorphic events [12]. The Limpopo belt is divided into three tectonic domains based on structural, lithological and metamorphic arguments. These tectonic domains are the northern marginal zone (NMZ), the central zone (CZ) and the southern marginal zone (SMZ) and they are bounded 


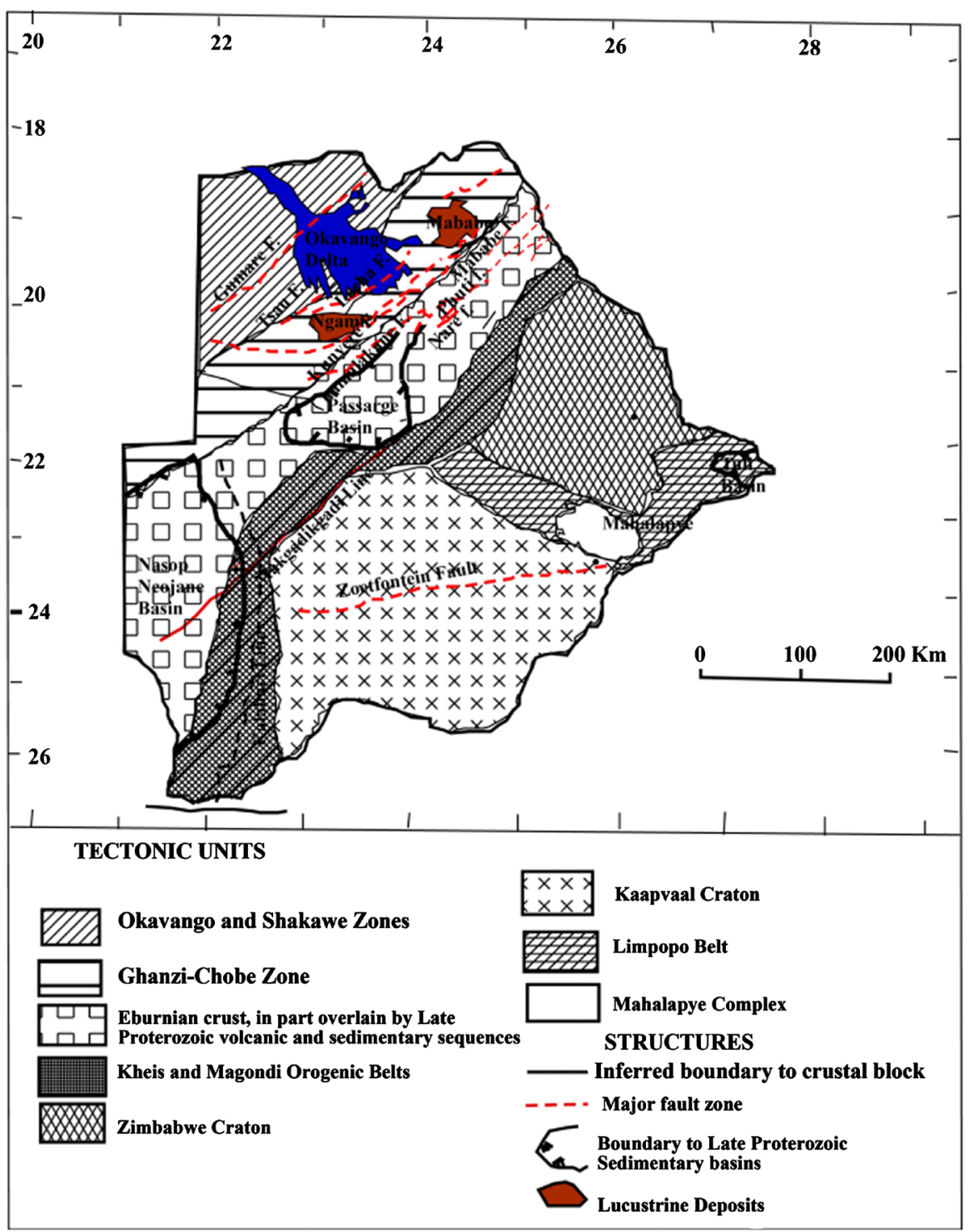

Figure 2. The major structural features and tectonic units in Botswana [12] [13] [14].

by ductile shear zones [13]. The age of the tectonic events that led to the formation of the Limpopo belt is not well known [13]. The tectonic domain of the Limpopo belt that is exposed in Botswana is the central zone and is sub-divided into four litho-stratigraphic complexes: the Semolale complex, the Phikwe complex, the Baines drift complex and the Mahalapye complex and in most cases, the margins of these complexes coincide with tectonic discontinuities [13] and the Mahalapye complex is where Moiyabana is located [15].

\section{Seismicity of Botswana}

Seismicity is the frequency of occurrence of earthquakes in a region and Botswana is generally characterized with a low level of seismicity, this is because it is located on the Kaapvaal and Zimbabwe cratons [13] [16]. These cratons are old and stable parts of the continental lithosphere and Archean rocks are the oldest 
rocks known on Earth [17]. Earthquakes with a magnitude greater than 7 are rare across southern Africa and seismic activity in southern Africa is mostly associated with the East African Rift System (EARS) [10]. Before 1949, Botswana was not recognized of having any seismic activity because there were no seismic networks to monitor seismic activity in Botswana. According to [16] [18] between 1949 and 1951 the first modern seismographic network was set up in South Africa, and it was during this period that seismic activity in Botswana was first recognized.

Most of Botswana's historical seismic activity has predominantly been experienced in the Okavango Delta Region (ODR) [12] [16]. According to [19], the delta is a result of tectonic activity since the Cretaceous as extensional forces caused the development of the main Gumare and Thamalakane faults. A major seismic swarm was observed in the ODR between 1951 and 1953, which culminated in Richter magnitudes 6.1 and 6.7 events on 11 September and 11 October 1952, respectively [16] [18]. These earthquakes were the first two large earthquakes to be instrumentally recorded in Botswana and resulted in the start of seismic monitoring in Botswana [16]. According to a study by [12] within 19661983, the main area of seismicity was the ODR and the seismicity was highest along the south eastern edge of the delta with association to the NE-SW striking faults. However, this is not the only area that is seimically active, other parts of the country like the southern, eastern and central parts show a certain level of seismicity, with the south western part showing the highest micro-seismic activity [12].

In 2013, a temporary seismic network was set up around Botswana in order to get a better understanding of the structure of Botswana's crust and seismicity and this network was named the NARS project and it consisted of 21 broadband seismic stations [8]. These stations added to the already existing Botswana Seismological Network (BSN) and two seismic stations in Maun from Africa Array (AA) and the LBTB from the Global Seismic Network (GSN) [8] [16]. This temporary network was a collaboration project done by seismologists from the University of Utrecht, University of Twente, Botswana Geological Survey (now Botswana Geoscience Institute (BGI)) and the AA team. In March 2018, the stations were officially handed over to the BGI and these stations formed part of the BSN and are used to monitor seismic activity in Botswana.

\section{Methodology}

In this study, the data used was recorded by the NARS project with station distribution shown in Figure 3. The NARS database was searched for seismic events starting with the month of $1^{\text {st }}$ December 2016 through to $2^{\text {nd }}$ April 2017 to identify possible foreshock events for a period of 4 months associated with the Moiyabana earthquake that occurred in central Botswana on the $3^{\text {rd }}$ April 2017. Meanwhile, the aftershock data mostly covers the first few days and a few months after the mainshock. This network was not biased to any portion of the 


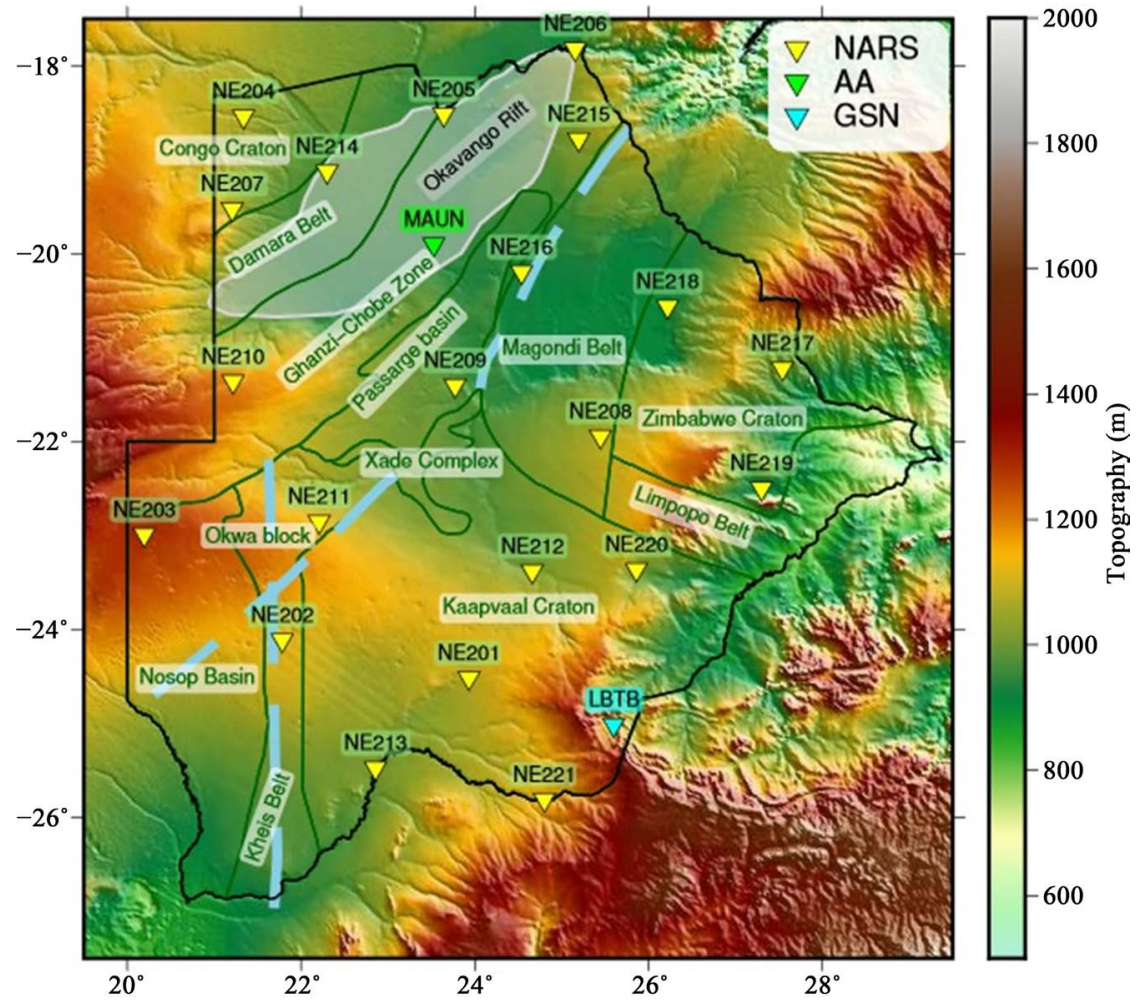

Figure 3. The NARS network in Botswana [8].

country unlike the previous network that was in the ODR [16] hence best suited to understand the seismicity of Botswana.

The Seisan earthquake analysis software by [20] was used to analyze both foreshock and aftershock events. However, the velocity model used in this analysis is the regional model BPI1 by [21]. This is a model that was derived from a study that was carried out to better understand the crust and upper mantle to depths of $320 \mathrm{~km}$ beneath southern Africa using $\mathrm{P}$ waves generated by regional events and mining induced events [21]. In this study, only first arrival $\mathrm{P}$ phases were used because using all available phases is heavily dependent on the velocity model employed. However, the $\mathrm{P}$ wave first arrivals based solution is least influenced by errors in the velocity estimate used since it only assumes that the velocity model is the same for all the stations. Although, the preference was to pick phases on unfiltered seismograms, in some of the seismograms the first arrivals were not very clear due to noise (unwanted vibrations) hence a bandpass filter with a frequency range of $1-5 \mathrm{~Hz}$ was used to remove the noise. The events filtered were those found to have residuals outside the range of $\pm 1 \mathrm{~s}$ and this was applicable to both the foreshock and aftershock events.

\section{Seismic Events Parameters}

The analysis yielded a total of 30 good seismic events (recorded by several stations and with good GPS timings) of which 9 were foreshocks and the remaining 21 were aftershocks. These were tabulated as shown in Table 1 and Table 2 . The 
Table 1. Foreshock events parameters.

\begin{tabular}{ccccccc}
\hline Event & Date & $\begin{array}{c}\text { Origin Time (Local } \\
\text { Time) }(\mathrm{hr}: \min : \mathrm{sec})\end{array}$ & $\begin{array}{c}\text { Latitude } \\
\left({ }^{\circ} \mathrm{S}\right)\end{array}$ & $\begin{array}{c}\text { Longitude } \\
\left({ }^{\circ} \mathrm{E}\right)\end{array}$ & $\begin{array}{c}\text { Magnitude } \\
\left(\mathrm{M}_{\mathrm{L}}\right)\end{array}$ & $\begin{array}{c}\text { Depth } \\
(\mathrm{km})\end{array}$ \\
\hline F1 & $2016 / 12 / 16$ & $16: 09: 47.0$ & -24.51 & 24.74 & 2.6 & 0.9 \\
F2 & $2016 / 12 / 17$ & $00: 39: 34.0$ & -21.30 & 21.40 & 2.7 & 1.2 \\
F3 & $2016 / 12 / 21$ & $13: 48: 56.0$ & -18.70 & 21.40 & 2.4 & 15 \\
F4 & $2016 / 12 / 29$ & $13: 56: 30.0$ & -20.60 & 26.20 & 2.5 & - \\
F5 & $2017 / 01 / 02$ & $19: 48: 09.0$ & -19.50 & 23.83 & 3.3 & 16.6 \\
F6 & $2017 / 02 / 17$ & $14: 39: 54.0$ & -23.50 & 24.70 & 1.8 & 0.1 \\
F7 & $2017 / 03 / 10$ & $16: 01: 17.0$ & -22.90 & 22.20 & 2.8 & 0.1 \\
F8 & $2017 / 03 / 14$ & $17: 16: 37.0$ & -22.10 & 25.40 & - & - \\
F9 & $2017 / 03 / 21$ & $15: 06: 55.0$ & -19.20 & 23.20 & - & - \\
\hline
\end{tabular}

NB: Dashes indicate parameters which could not be resolved due to insufficient stations or noisy data.

Table 2. Aftershock events parameters.

\begin{tabular}{|c|c|c|c|c|c|c|}
\hline Event & Date & $\begin{array}{l}\text { Origin Time (Local } \\
\text { Time) (hr:min:sec) }\end{array}$ & $\begin{array}{l}\text { Latitude } \\
\left({ }^{\circ} \mathrm{S}\right)\end{array}$ & $\begin{array}{l}\text { Longitude } \\
\quad\left({ }^{\circ} \mathrm{E}\right)\end{array}$ & $\begin{array}{l}\text { Magnitude } \\
\left(\mathrm{M}_{\mathrm{L}}\right)\end{array}$ & $\begin{array}{l}\text { Depth } \\
(\mathrm{km})\end{array}$ \\
\hline $\mathrm{A} 1$ & $2017 / 04 / 03$ & $20: 11: 24.8$ & -22.69 & 25.12 & 4.8 & 12.1 \\
\hline A2 & $2017 / 04 / 03$ & 20:38:13.1 & -22.66 & 25.30 & 3.7 & 7.3 \\
\hline $\mathrm{A} 3$ & $2017 / 04 / 03$ & $22: 27: 59.9$ & -22.72 & 25.20 & 3.6 & 1.0 \\
\hline A4 & $2017 / 04 / 04$ & 01:16:23.5 & -22.69 & 25.30 & 3.7 & 1.8 \\
\hline A5 & $2017 / 04 / 04$ & 02:57:00.0 & -22.66 & 25.02 & 2.8 & 8.0 \\
\hline A6 & $2017 / 04 / 04$ & $06: 19: 22.0$ & -22.72 & 25.20 & 3.8 & 9.5 \\
\hline A7 & $2017 / 04 / 04$ & $11: 31: 59.5$ & -22.97 & 25.61 & 3.5 & 0.9 \\
\hline A8 & $2017 / 04 / 04$ & 11:59:45.9 & -22.79 & 25.15 & 4.1 & 0.1 \\
\hline A9 & $2017 / 04 / 04$ & 20:53:04.6 & -23.02 & 25.44 & 4.2 & 1.1 \\
\hline A10 & $2017 / 04 / 04$ & $21: 41: 56.8$ & -22.66 & 25.08 & 4.0 & 18.0 \\
\hline A11 & $2017 / 04 / 05$ & 02:55:51.7 & -22.55 & 25.06 & 5.3 & 0.1 \\
\hline A12 & $2017 / 04 / 05$ & $04: 48: 24.0$ & -23.01 & 27.63 & 3.7 & 0.1 \\
\hline A13 & $2017 / 04 / 06$ & 09:33:52.0 & -22.63 & 25.63 & 4.4 & 21.6 \\
\hline A14 & $2017 / 04 / 07$ & 04:08:19.8 & -22.62 & 25.09 & 3.8 & 0.1 \\
\hline A15 & $2017 / 04 / 07$ & 23:08:41.9 & -22.89 & 25.29 & 3.7 & 7.0 \\
\hline A16 & $2017 / 04 / 08$ & $18: 21: 51.3$ & -21.91 & 23.88 & 3.3 & 12.6 \\
\hline A17 & $2017 / 04 / 08$ & $19: 31: 30.2$ & -22.81 & 25.24 & 3.6 & 27.6 \\
\hline A18 & $2017 / 04 / 08$ & $21: 55: 33.2$ & -22.57 & 25.06 & 4.8 & 14.2 \\
\hline A19 & $2017 / 06 / 21$ & 09:10:32.8 & -22.70 & 25.24 & 4.4 & 8.2 \\
\hline A20 & $2017 / 07 / 04$ & $13: 37: 07.7$ & -22.71 & 25.06 & 4.8 & 6.7 \\
\hline A21 & $2017 / 08 / 12$ & $04: 37: 48.0$ & -23.62 & 25.68 & 4.9 & 3.3 \\
\hline
\end{tabular}


spatial distribution of epicenters of the foreshocks and aftershocks denoted with letters $\mathrm{F}$ and $\mathrm{A}$, respectively, was displayed on Google Earth in relation to the mainshock (ME) as shown in Figure 4. The aftershocks were numbered according to the time of their occurrence; hence A1 would be the first aftershock to be recorded in the database relative to the $\mathrm{ME}$.

\section{Discussions}

The foreshock activity could likely be dominated by the background seismic activity because we assumed that since Botswana has generally low seismicity then the background activity is rare hence an event that occurs before the ME is more likely to be a foreshock. From Figure 4, the foreshock events have a non-uniform and relatively random distribution across Botswana but no foreshocks occurred in the southwestern part of the country. Events F3, F5 and F9 occurred around the Okavango Delta, which is known to have the most historical seismic activity in the country. To view the pattern of the foreshocks, those close to within a 300 $\mathrm{km}$ radius to the mainshock (ME) are events F1, F4, F6 and F8 (Figure 4). These foreshock events form a linear pattern that is trending NE-SW which is consistent with fault zones within the ODR. The proximity of foreshocks F6, F7 and F8 to the ME probably indicates that foreshock events migrate slowly toward the $\mathrm{ME}$ as time increases toward the time of the ME.

To determine the contribution of major fault zones and tectonic units in the activation of the foreshocks, Figure 5 was produced and from this figure, most of the foreshocks are far from any of the major faults and boundaries of the tectonic units. The foreshocks that are closest to the ME are events F6 and F8 which

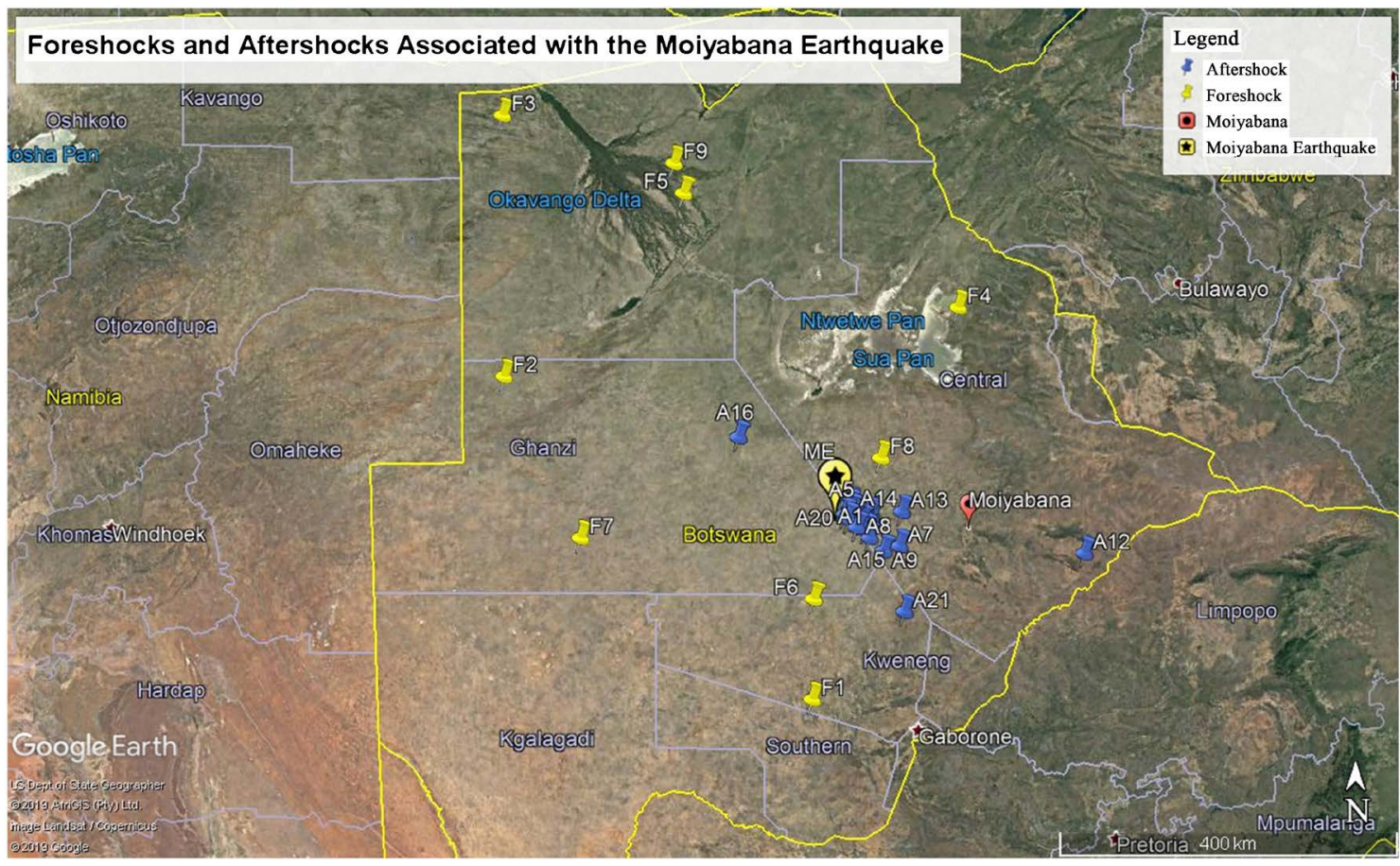

Figure 4. The spatial distribution of epicenters of the foreshocks and aftershocks on Google Earth. 


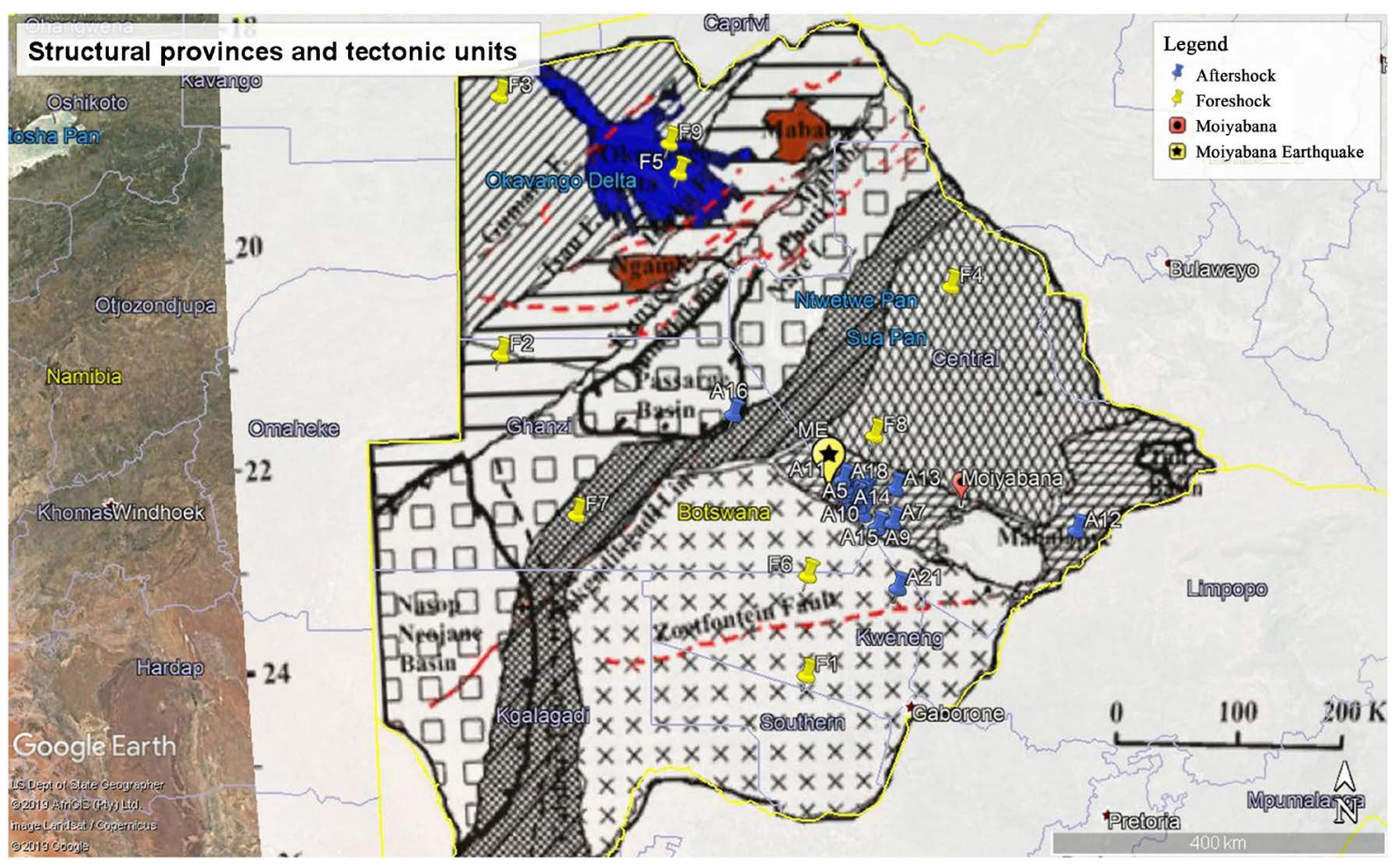

Figure 5. Google Earth map of foreshock and aftershock epicentres overlain with a map of major structural features and tectonic units in Botswana (Modified after [12]).

can be associated with the Zoetfontein fault and the Zimbabwe craton-Limpopo mobile belt junction, respectively. However, foreshock events F1, F5 and F9 are relatively close to some of the major fault zones in the country. Events F1 and F6 are also close to the Zoetfontein fault whereas in the ODR, event F5 is near the Lecha fault and event F9 is relatively close to the Chobe fault. Foreshock activity in Figure 4 does not reveal any clustering around the mainshock, although according to [22], the mainshock was preceded by two foreshock swarm-like sequences.

From Figure 4, the spatial distribution of aftershock epicentres shows that a majority of them occurred within a close proximity to the ME (a total of 19 aftershock events plotted close to the ME). These events can be used to understand the general direction of propagation of the aftershocks on a local scale (within the area of the ME) since they are at close proximity to the ME. The remaining aftershocks (A12, A16 \& A21) plotted further away and at an average distance of approximately $240 \mathrm{~km}$ from the ME. These three events can be used to relate them to the regional tectonics of central Botswana. The largest aftershock in Table 2 is event A11 that occurred on the third day following the ME. This aftershock had a magnitude of 5.3 that results in a difference of 1.2 with that of the ME and hence, validates Båth's law which states that the average difference in magnitude between a mainshock and its largest aftershock is 1.2, regardless of the mainshock magnitude [23]. Foreshock and aftershock activity occurred at shallower depths compared to that of the ME as shown in Table 1 and Table 2.

According to [5], the Moiyabana earthquake occurred in an area not associ- 
ated to any active fault systems. Therefore, to come up with a better interpretation on the propagation of the aftershock events with respect to the mainshock, the aftershock epicentres were also overlain with the tectonic map of Botswana as shown in Figure 5. This was an attempt to identify any possible propagation associated with the regional tectonics of central Botswana. The spatial distribution of aftershocks in Figure 5 shows that most aftershocks are trending in a northwest-southeast direction and this probably indicates the rupture plane of the Moiyabana earthquake. A previous study by [10] suggests that two fault planes link the mainshock and the aftershocks. In addition, most aftershocks mainly lie within the Limpopo mobile belt that is sandwiched between the Kaapvaal craton to the south and Zimbabwe craton to the north. Furthermore, the aftershocks concentration to the south reveals a close relation in demarcating the boundary of the Kaapvaal craton and the Limpopo mobile belt.

The propagation of the aftershocks in relation to the mainshock confirms the existence of faults identified from aeromagnetic data by [15] and also suggests a possibility of the presence of unmapped faults that link the mainshock and the aftershocks. In addition, the aftershock events agree well with the study by [12] that the central part of Botswana is also one of the areas with an increased seismic activity compared with the northern part where the ODR is located. These aftershocks probably indicate that after the mainshock, the release of stress re-activated the pre-existing planes of weakness in the vicinity of the ME and farther away from the ME. This is evidenced by the clustering of events along the Kaapvaal craton-Limpopo mobile belt junction and the presence of events A16 and A21, that occurred at the Passarge basin-Magondi belt boundary and along the Zoetfontein fault, respectively. Hence, indicating that the aftershocks also reflect the large-scale tectonic processes in central Botswana.

\section{Conclusion}

The spatial distribution of foreshock events associated with the Moiyabana earthquake reflects a relatively random distribution of epicentres across Botswana; most likely this suggests triggered seismicity. However, the spatial distribution of aftershock events coincides with major structural features and reflects the large-scale tectonic processes within central Botswana. Most aftershocks are clustered within the Limpopo mobile belt which is sandwiched between the Kaapvaal and Zimbabwe cratons. The propagation of the aftershocks is attributed to the re-activation of pre-existing planes of weakness mainly along the Kaapvaal craton and Limpopo mobile belt junction. The spatial distribution of the aftershock events suggests that they occurred within the same fault plane as the mainshock. Both foreshock and aftershock events reflect the re-activation of the Zoetfontein fault, a regional fault in southern Africa. This study confirms that the central part of Botswana is seismically active. Finally, the spatial distribution of foreshock and aftershock events allows for a better understanding of the seismic hazard associated with the different regions. 


\section{Acknowledgements}

We greatly appreciate all those whose involvement made sure that the NARS project was successful and the Botswana Geoscience Institute for the data used. We are grateful to the two anonymous reviewers for their helpful comments.

\section{Conflicts of Interest}

The authors declare no conflicts of interest regarding the publication of this paper.

\section{References}

[1] Fronabarger, A.K. (2013) Earthquakes. Salem Press Encyclopedia of Science.

[2] Mussett, A.E. and Khan, M.A. (2009) Looking into the Earth: An Introduction to Geological Geophysics. Cambridge University Press, Cambridge.

[3] Stein, S. and Wysession, M. (2003) An Introduction to Seismology, Earthquakes, and Earth Structure. Blackwell Publishing, Hoboken.

[4] Shearer, P.M. (2009) Introduction to Seismology. Cambridge University Press, Cambridge. https://doi.org/10.1017/CBO9780511841552

[5] Materna, K., Wei, S., Wang, X., Heng, L., Wang, T., Chen, W., Burgmann, R., et al. (2019) Source Characteristics of the 2017 Mw6.4 Moijabana, Botswana Earthquake, Rare Lower-Crustal Event within an Ancient Zone of Weakness. Earth and Planetary Science Letters, 506, 348-359. https://doi.org/10.1016/j.epsl.2018.11.007

[6] Havskov, J. and Ottemoller, L. (2010) Routine Data Processing in Earthquake Seismology. Springer, Berlin. https://doi.org/10.1007/978-90-481-8697-6

[7] Kampunzu, A.B., Armstrong, R.A., Modisi, M.P. and Mapeo, R.B.M. (2000) Ion Microprobe U-Pb Ages on Dedrital Zircon Grains from the Ghanzi Group: Implications for the Identification of a Kibaran-Age Crust in Northwest Botswana. Journal of African Earth Sciences, 30, 579-587. https://doi.org/10.1016/S0899-5362(00)00040-3

[8] Fadel, I., van der Meijde, M. and Paulssen, H. (2018) Crustal Structure and Dynamics of Botswana. Journal of Geophysical Research: Solid Earth, 123, 10,659-10,671. https://doi.org/10.1029/2018JB016190

[9] Key, R.M. and Ayres, B. (1998) The 1998 Edition of the National Geological Map of Botswana. Journal of African Earth Sciences, 30, 427-451. https://doi.org/10.1016/S0899-5362(00)00030-0

[10] Midzi, V., Saunders, I., Manzunzu, B., Kwadiba, M.T., Jele, V., Mantsha, R., Zulu, B.S., et al. (2018) The 03 April 2017 Botswana M6.5 Earthquake: Preliminary Results. Journal of African Earth Sciences, 143, 187-194. https://doi.org/10.1016/j.jafrearsci.2018.03.027

[11] Tugume, F., Nyblade, A., Julia, J. and van der Meijde, M. (2013) Precambrian Crustal Structure in Africa and Arabia: Evidence Lacking of Secular Variation. Tectonophysics, 609, 250-266. https://doi.org/10.1016/j.tecto.2013.04.027

[12] Nthaba, B., Simon, R.E. and Ogubazghi, G.M. (2018) Seismicity Study of Botswana from 1966-2012. International Journal of Geosciences, 9, 707-718. https://doi.org/10.4236/ijg.2018.912043

[13] Carney, J.N., Aldiss, D.T. and Lock, N.P. (1994) The Geology of Botswana. Bulletin Vol. 37, Department of Geological Survey, Lobatse, Botswana, 113 p. 
[14] McCarthy, T.S. (2013) The Okavango Delta and Its Place in the Geomorphological Evolution of Southern Africa. South African Journal of Geology, 116, 1-54. https://doi.org/10.2113/gssajg.116.1.1

[15] Ranganai, R.T., Kampunzu, A.B., Atekwana, E.A., Paya, B.K., King, J.G. and Koosimile, D.I. (2002) Gravity Evidence for a Larger Limpopo Belt in Southern Africa and Geodynamic Implications. Geophysics Journal International, 149, F9-F14. https://doi.org/10.1046/j.1365-246X.2002.01703.x

[16] Simon, R.E., Kwadiba, M.T.O., King, J.G. and Moidaki, M. (2012) A History of Botswana's Seismic Network. Botswana Notes and Records, 44, 184-192.

[17] Skinner, B.J., Porter, S.C. and Park, J. (2003) Dynamic Earth. John Wiley and Sons, New York.

[18] Hutchins, D.G., Hutton, L.G., Hutton, S.M., Jones, C.R. and Loenhert, E.P. (1976) A Summary of the Geology, Seismicity, Geomorphology and Hydrogeology of the Okavango Delta. Geological Survey, Botswana, Bulletin 7.

[19] Modisi, M.P., Atekwana, E.A., Kampunzu, A.B. and Ngwisanyi, T.H. (2000) Rift Kinematics during the Incipient Stages of Continental Extension: Evidence from the Nascent Okavango Rift Basin, North-West Botswana. Geology, 28, 939-942. https://doi.org/10.1130/0091-7613(2000)28<939:RKDTIS>2.0.CO;2

[20] Havskov, J. and Ottemoller, L. (1999) Seisan Earthquake Analysis Software. Seismological Research Letters, 70, 532-534. https://doi.org/10.1785/gssrl.70.5.532

[21] Wright, C., Kwadiba, M.T.O., Kgaswane, E.M. and Simon, R.E. (2002) The Structure of the Crust and Upper Mantle to Depths of $320 \mathrm{~km}$ beneath the Kaapvaal Craton, from P Wave Arrivals Generated by Regional Earthquakes and Mining-Induced Tremors. Journal of African Earth Sciences, 35, 477-488. https://doi.org/10.1016/S0899-5362(02)00157-4

[22] Gardonio, B., Jolivet, R., Calais, E. and Leclere, H. (2018) The April 2017 Mw6.5 Botswana Earthquake: An Intraplate Event Triggered by Deep Fluids. American Geophysical Union. https://doi.org/10.1029/2018GL078297

[23] Båth, M. (1965) Lateral Inhomogeneities in the Upper Mantle. Tectonophysics, 2, 483-514. https://doi.org/10.1016/0040-1951(65)90003-X 